\title{
非接触モード超高真空原子間力顕微鏡による 化合物半導体表面の原子分解能観察*
}

\author{
菅原 康弘 ${ }^{* *}$. 大田 昌弘 $* *, * * *$.上山 仁司 ${ }^{* *}$. 森田 清三**
}

（受理1995年 7 月 5 日，掲載決定1995年 9 月 19日）

\author{
Atomic Resolution Imaging of Compound Semiconductor \\ Surface with Non-contact UHV-AFM \\ Yasuhiro SUGAWARA, Masahiro OHTA, \\ Hitoshi UEYAMA and Seizo MORITA
}

(Department of Physics, Faculty of Science, Hiroshima University, 1-3-1, Kagamiyama, Higashi-Hiroshima, Hiroshima)

(Received July 5, 1995, Accepted September 19, 1995)

\section{1. 原子間力顕微鏡による真の原子分解能}

探針先端と試料表面との間に働く原子間力を利用する 原子間力顕微鏡 $(\mathrm{AFM})^{1)}$ は, 走査型トンネル顕微鏡 （STM）では観察できない絶縁体表面の構造も超高分解 に観察できる装置として発展してきた，実際，AFMを 用いて表面の原子構造や分子構造を観察できたという数 多くの報告がある。しかし，「AFM は本当に探針先端 の 1 個の原子と試料表面の 1 個の原子の間に働く単一の 原子間力を測定しているか？」といら疑問が投げかけら れている.この疑問は AFM 動作の本質にかかわる極め て重要な問題である.

AFM が開発された当初，探針と試料表面との間に働 く力の距離依存性が強い接触 (斥力) モードで, グラフ フイトのよらな層状物質で原子分解能が得られた。 しか し, $10^{-8} \sim 10^{-5} \mathrm{~N}$ もの強い斥力荷重で測定されており, 探針先端の 1 個の原子あるいは試料表面の 1 個の原子が 塑性変形を起こさずに支えられる荷重の限界（単原子荷 重限界）を大きく越えて扣り，非常に多数の原子と原子

* 平成 7 年 3 月 31 日 第 42 回応用物理連合講演会で講演

** 広島大学理学部物理学科( ( 739 広島県東広島市鏡山 1-3-1)

*** 日本学術振興会特別研究員
の接触が起こっているはずだとの指摘があった。その 後, 接触により䢃開したフレークと試料表面との大面積 の摩擦が原子分解能の原因ではないかとの主張があっ た2). また，STMで観察される原子レベルの欠陥が AFM では観察できないといら観察結果も報告された. そこで, 単原子観察条件として,「䢃開しにくい3次元 結晶での原子分解能での観察と大面積の接触では実現で きない急峻な単原子ステップの観察」が求められた。こ れは, 塩化ナトリウム型のイオン結晶の観察などで実現 されている3,4).さらに, 現在では, 「点欠陥のような非 周期性の原子構造の観察」5)や「原子ステップ近傍での

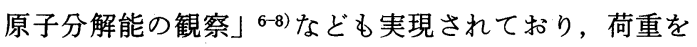
十分小さくすることにより接触モードの AFM であって も単原子観察は可能だと信じられるようになりつつあ る.しかし，これらを実現するための条件は極めて厳し い.

また, 以上の報告は, 比較的不活性な表面が中心であ る.ダングリングボンドをるつ半導体清浄表面のよらに 活性な表面では, 探針先端の原子と半導体表面の原子が 結合を作り, 走査に伴い結合が切れたりして原子レベル の破壊が起こり, 原子分解能観察は不可能であると考え られてきた。これまでの半導体清浄表面の AFM 測定に 関しては, ダングリングボンドを水素原子で終端し不活 
性化することにより，Si(111)表面を超高真空（UHV） 中で原子分解能で観察した報告がある9)。また，探針先 端をテフロンでュートし不活性化することにより， $\mathrm{Si}(111) 7 \times 7$ 再構成表面の長周期構造を観察した報告も ある10)。しかし，これは表面の構造ではなく摩擦の効果 を画像化したものである．ダングリングボンドを有する III-V 族 ${ }^{11-13)}$ や II-U 族 ${ }^{14)}$ 化合物半導体清浄表面を不活性 化処理することなしに原子分解能で観察することに成功 した例もある。しかし，接触モードで測定された上記の 半導体表面は, それほど活性ではない. 実際, 非常に活 性な表面を原子分解能で測定するためには，探針と試料 表面との接触は避けなければならない。

他方，探針と試料表面とが接触せず測定する非接触 モードでは，探針先端の原子と試料表面との原子との間 の化学結合のような強い相互作用は生じない，乙かし， 非接触の引力領域では, 探針先端と試料表面との間に働 く力が非常に弱く, またその距離依存性も弱いため, 技 術的に原子分解能観察は非常に困難であると考兄られて きた。これまで, $\mathrm{Si}(111)$ 表面15)や $\mathrm{KCl}(100)^{16)}$ 表面の高 分解能観察が試みられた．しかしながら，原子ステップ は観察できたが表面の原子配列は観察できず, 垂直方向 の分解能は原子レベルに達しているが水平方向の分解能 は原子レベルに達していなかった，最近, $\mathrm{Si}(111) 7 \times 7$ 再構成表面のアダトムを不安定であるが狭い範囲で観察 できたといら報告が相次いでなされだ7,18)。しかし， $\mathrm{Si}(111) 7 \times 7$ 再構成表面のアダトム間の距離は他の多く の表面の原子間隔よりかなり長い、また, コーナーホー ルの凹凸も $0.2 \mathrm{~nm}$ と大きい。このように，非接触モ一 ドで動作する AFM の水平分解能は依然不十分である.

本稿では，非接触モードで動作する超高真空原子間力 顕微鏡（UHV-AFM）により, 半導体清浄表面を原子 分解能で観察した結果について報告する ${ }^{19)}$ ，具体的に は, 変調法を利用した超高感度 UHV-AFM を開発する ことにより, $\operatorname{InP}(110)$ 䢃開表面の原子像だけでなく， 原子レベルの欠陥も明瞭に観察できたので報告する.

\section{2. 超高真空原子間力顕微鏡による非接触モ 一ド測定}

\section{1 䢃開機構を有する超高真空原子間力顕微鏡ユニ} ッ ${ }^{20)}$

図 1 亿試料の䢃開機構を有する UHV-AFM ニニット の構成を示す. 通常の AFM では, 試料をチューブスキ ャナー（3 次元微動機構）により走查するが, この構成 では試料の擘開時にかなりの荷重がチューブスキャナー にかかるため, チューブスキャナーが破壊される恐れが ある. そこで，てこを走査する構成の AFM とした.す

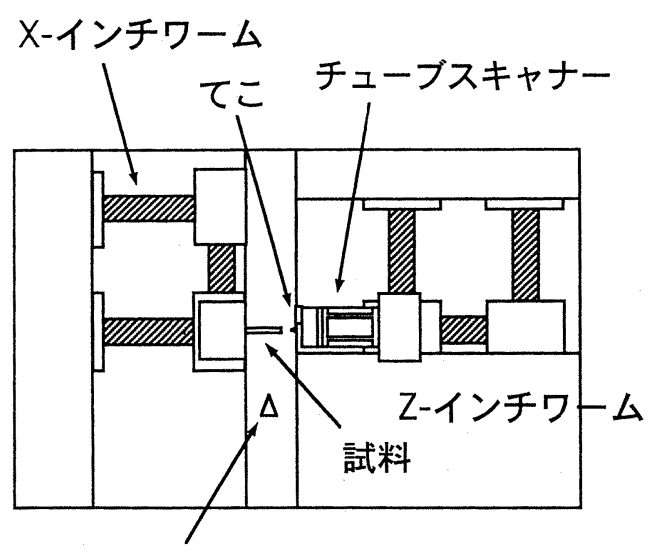

\section{䢃開用ブロック}

図 1 試料の䢃開機構を有する超高真空原子間力顕 微鏡ニニットの構成

なわち,てこの微小变位検出機構を超小型化し, チュー ブスキャナーの内部に組み込んだ.てこの微小変位は, 光ファイバーを用いた光干渉方式变位計により検出し た ${ }^{21)}$. この変位検出方式の利点は, 光ファイバー以外の 光部品（半導体レーザーやホトダイオード，方向性結合 器など）をすべて真空チャンバーの外に置くことができ るため, 変位検出機構を小型・軽量化できることにあ る. また， 2 軸の移動機構（具体的には，構成が簡単で 小型・軽量化が容易なインチワーム) を有している.

$\mathbf{X}$ 軸インチワームは, 試料を䢃開し, その䢃開表面を 広範囲にサーチ寸るために用いる。すなわち, 試料台に 試料をセットした状態で， $\mathbf{X}$ 軸インチワームを䢃開用 ブロックの方に移動させ，試料を䢃開用ブロックに押 し付け，その時に試料にかかる強い荷重により試料を䢃 開する。また， $\mathbf{Z}$ 軸インチワームは，てこと試料の粗 動接近機構として用いる.

\section{2 変調法を用いた超高感度力検出系}

探針と試料表面とが接触しない引力領域で測定を行兄 ば，探針先端 1 個の原子と試料表面の 1 個の原子との間 に働く単一の原子間力を測定できる可能性が高い。しか し, 一般に, 引力は長距離力であり, また，その大きさ の距離依存性も小さく, 引力自体が非常に弱い力であ る. したがって, 静的な力の検出では感度不足のため, 高分解能観察を実現することは到底不可能である，そこ で, 力の検出感度を向上させるため, てこの共振を応用 した変調法を用いた，図 2 において, 右側の曲線がてこ の自由振動状態における共振特性である. この状態で, 探針と試料を接近させると，探針と試料表面との間に働 く力勾配により，てこの実効的なバネ定数が変化する. 


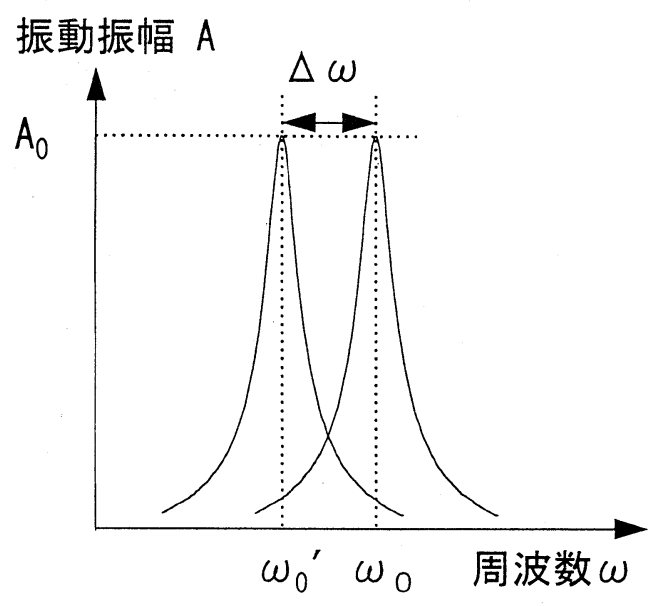

図 2 非接触モードでの力勾配測定の概念

その結果, 図 2 の左側の曲線のように共振周波数が変化 する. 共振周波数と力勾配との関係は, 以下の関係式で 与えられる。

$$
\boldsymbol{\omega}=\sqrt{\left(\mathbf{k}-\mathbf{F}^{\prime}\right) / \mathbf{m}}
$$

ここで， $\mathbf{k}, \mathbf{m}$ および $\mathbf{F}^{\prime}$ は，それぞれ，てこのバネ定 数, てこの質量, および探針と試料との間に働く力勾配 である. したがって，共振周波数の変化を測定すること により，探針に働く力勾配を高感度に検出できる.

共振周波数の変化を検出する方法としては, 大別し て，振動振幅の変化によって間接的に周波数変化を測定 する方法（スロープ検出法）と周波数変化を直接的に測 定する方法 (FM (Frequency Modulation) 検出法) ${ }^{22)}$ と がある．スロープ検出法では，てこを共振点から少しず れた周波数で強制振動させる.てこに働く力勾配により 共振周波数が变化して，てこの振動振幅(あるいは位相） が変化する.このスロープ検出法では, 信号の帯域幅が 一定ならば，共振曲線の勾配が急な（Q值が大きい） ほど，信号対雑音比（S/N，あるいは，検出感度）が向 上する。しかし， $\mathbf{Q}$ 值が非常に大きくなった場合，て この振動振幅（あるいは位相）の変化を十分な感度で検 出するには，検出系の帯域幅をかなり狭くする必要があ る. 例えば, $10^{-1} \mathrm{~Pa}$ 以下の真空中ではてこが空気の粘 性抵抗を受けなくなるため，Q值は空気中（Q～100） での動作に比べて著しく増加する（例えば $\mathbf{Q}>20000 ）$. したがって, 真空中では検出系の帯域幅を狭める必要が あり，動作速度が著しく低下する．さらに， $\mathbf{Q}$ 值の大 きなてこは，振動振幅（あるいは位相）の過渡特性が悪 化するため，動作速度を速くすることがますます困難に なる．このように，スロープ検出法では，本質的に真空 中での動作は困難である.

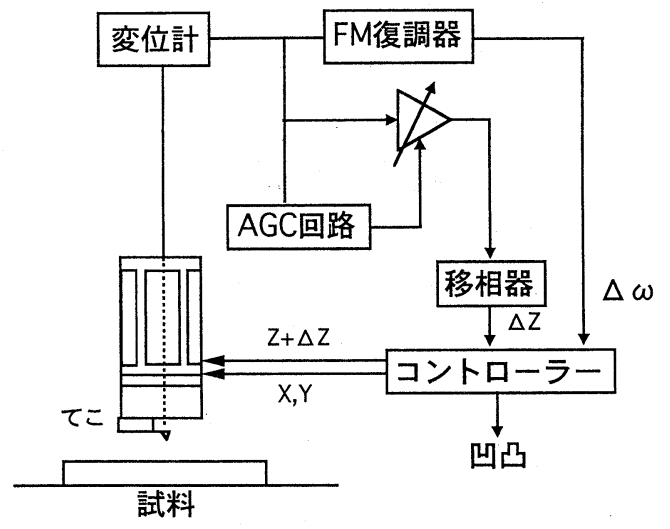

図 3 周波数变調 $(F M)$ 検出法を用いた非接触モ ード AFM の構成

そこで，てこの共振周波数を直接検出し，てこに働く 力勾配を求める FM 検出法を用いた．この方式では, $\mathbf{Q}$ 值の大きなてこであっても, その振動振幅の過渡特 性は問題とならず，また帯域幅も狭める必要もないの で, 真空中でも高速動作が可能となる. 図 3 に FM 検 出法を用いた非接触 AFM の構成を示す. AGC (Automatic Gain Control) 回路を用いた正帰還発振系により, てこを一定振幅で振動させ, その時のてこの振動周波数 の変化を LC 複同調回路からなる FM 復調器で検出し て, てこに働く力勾配を求めた。 な拈, 移相器は, 正帰 還が最大となるように位相調整を行らために使用した。 また，てこ加振用圧電体としては，てこ走査用チューブ スキャナーを使用した. てこに働く平均的な力勾配 $\mathbf{F}^{\prime}$ は, 近似的に次のように与えられる.

$$
\mathbf{F}^{\prime}=2 \mathbf{k} \Delta \omega / \omega_{0}
$$

ここで, $\mathbf{k}, \omega_{0}=\sqrt{\mathbf{k} / \mathbf{m}}$ および $\Delta \omega$ は, それぞれ，てこ のバネ定数, てこの機械的共振周波数および周波数变化 である。

\section{3 実験方法}

力を検出するてことして柔らかいてこを使用すると， てこに働く力の勾配が容易にてこのバネ定数を越えてし まい,てこが試料側にジャンプし, 試料と接触してしま う。てこと試料との接触を防ぐためには, 非常に堅いて こを使用する必要がある。そこで，バネ定数 $34 \mathrm{~N} / \mathrm{m}$, 機械的共振周波数 $161 \mathrm{KHz}$ の $\mathrm{Si}$ てを用いた。探針先 端の曲率半径は, 約 $10 \mathrm{~nm}$ 以下である.

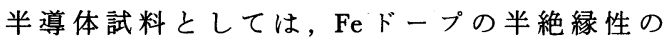
InP(001) ウェハーを用いた. なお, この半導体試料に は導電性がないため, STMでは, 表面を観察すること は不可能である.この試料を UHV-AFM ユニットに装 
着し, $4 \times 10^{-8} \mathrm{~Pa}$ 以下まで排気した後, 室温下で䢃開 を行い(110)表面を観察した。なお，非接触モード $\mathrm{AFM}$ 測定は, 力勾配が一定，すなわち周波数変化が一 定となるよ5にして行った.

\section{3. 化合物半導体清浄表面の原子分解能観察}

図 4 (a)に InP(110) 䢃開表面の非接触モードUHVAFM で得られた原子像を示す。走査範囲は $10 \mathrm{~nm} \times 10$ $\mathrm{nm}$ である. 周波数变化は $-8 \mathrm{~Hz}$ に設定した.この周波 数変化は, (2) 式より, 力勾配 $\mathbf{F}^{\prime}=-4 \times 10^{-3} \mathrm{~N} / \mathrm{m}$ に相 当する. 振動振幅は約 $50 \mathrm{~nm}_{\mathrm{p}-\mathrm{p}}$ である. 長方形の格子が 明瞭に分解されていることが分かる. 図4 (b) に示すよ うに $\operatorname{InP}(110)$ 表面は In 原子と P 原子からなる 1 次元の ジグザグ・パターンにより特徵づけられる. In 原子の ダングリングボンドの回りの電子が $\mathrm{P}$ 原子の側に移動 し, In 原子が P 原子の位置に比べて外側にシフト（再 構成）し，その結果ジグザグ線のなす面が(110)面に対 して回転した構造となっている。すなわち, InP(110) 䢃開面では再構成が起こり, In 原子がバルク側へ, P

(a)

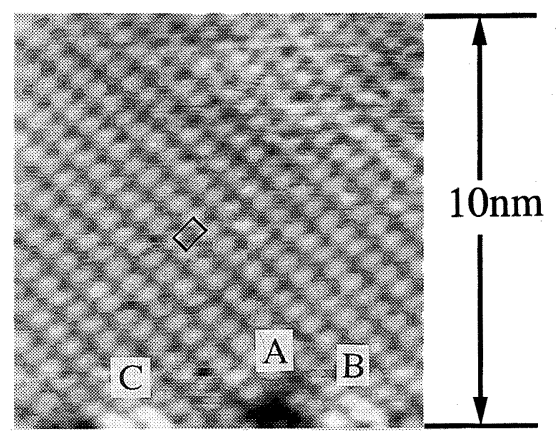

(b)

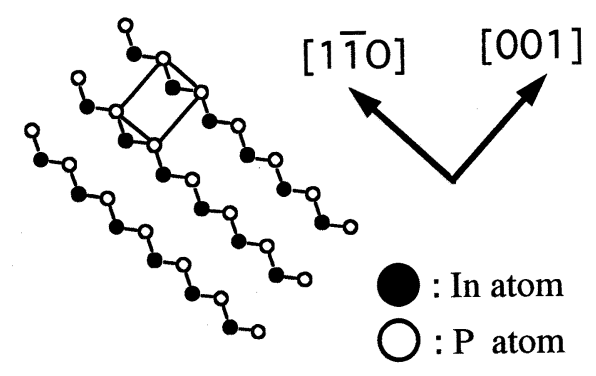

図 4 (a) InP(110) 䢃開表面の非接触モード AFM 観察結果. 画像の下部中央部 A に原子数個 からなる欠陥が観察された。 その周辺の B と C には吸着物と思われる構造が観察され た.

(b) InP (110)䢃開表面のモデル図
原子が真空側へ変位している. [001]および[110]方向の 起伏の間隔は， $0.58 \pm 0.06 \mathrm{~nm}$ および $0.43 \pm 0.04 \mathrm{~nm}$ と 測定された。これらの間隔は, 単位格子の長さ 0.587 $\mathrm{nm}$ および0.415 nm とほぼ一致する.これらの起伏は $\mathrm{P}$ 原子であると考えられる。なお，現在の所，In原子と $\mathrm{P}$ 原子の並びに対応するジグザグ線の構造を反映した画 像は得られていない.ジグザグ線の構造が得られない原 因としては，主に次の 2 つ理由が考えられる，1つ は, 現在の非接触モードAFM の分解能が，依然，不十 分であることによるものである.もら 1 つは，非接触モ ードAFM の画像化機構によるものである.すなわち, 化合物半導体表面と探針との間に㗢く力としては, フ ン・デル・ワールスカだケでなく, In 原子（カチオン） と $\mathrm{P}$ 原子（アニオン）との間の静電場に起因する静電 気的な力も考えられる. 非接触モード AFMでは, この 静電気的な力が主に検出されていることも考えられ，こ のため，どちらか一方の原子だけが画像化されるのかも しれない.これらの疑問については，今後，さらに理論 的・実験的に検討する必要があろう.

また，走査時の探針と試料表面との間の摩擦の影響 は, 非接触測定のため完全に除去されており, 全走查領 域において格子が明瞭に観察されている，すなわち，接 触モードでは，走查の開始時にチューブスキャナーは走 査を行っているが, 探針先端は静止摩擦力による試料表 面に引っ付いて動かないため，格子を観察できない領域 が存在する. しかし, 非接触モードでは, 摩擦が働かな いため格子を観察できない領域は存在しない.

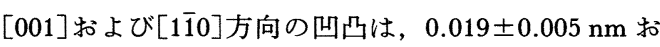
よび $0.012 \pm 0.005 \mathrm{~nm}$ と求まる.この凹凸は接触モード の AFM 測定で得られる值に比べて約 $1 / 6$ になっている. また，接触モードの AFM 測定結果と同じように，

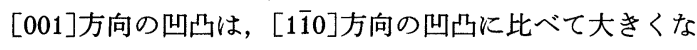
っている.これらの凹凸は探針の振動振幅や周波数变化 のような画像化パラメータに依存するので, 得られる AFM 像は表面の凹凸とわずかに異なっていると考える ことができる。また，下側中央の A で示す暗い領域は， 原子欠陥である。 また， C と B で示した位置に吸着物 らしき構造も観察できた。非接触モードUHV-AFMを 用いて，このような原子数個程度の欠陥を何度も明瞭に 観察することができた。これらの結果は, 非接触モード UHV-AFM が真の原子分解能を有していることを示唆 している.

次に, 図 5 に欠陥が存在する領域を連続して観察した 結果を示す．熱ドリフトにより位置が少しずれている が，明らかに欠陥が移動している様子を観察できたす なわち, 図 5(a)では, D と E の位置の欠陥は[001]方向 
(a)

(b)
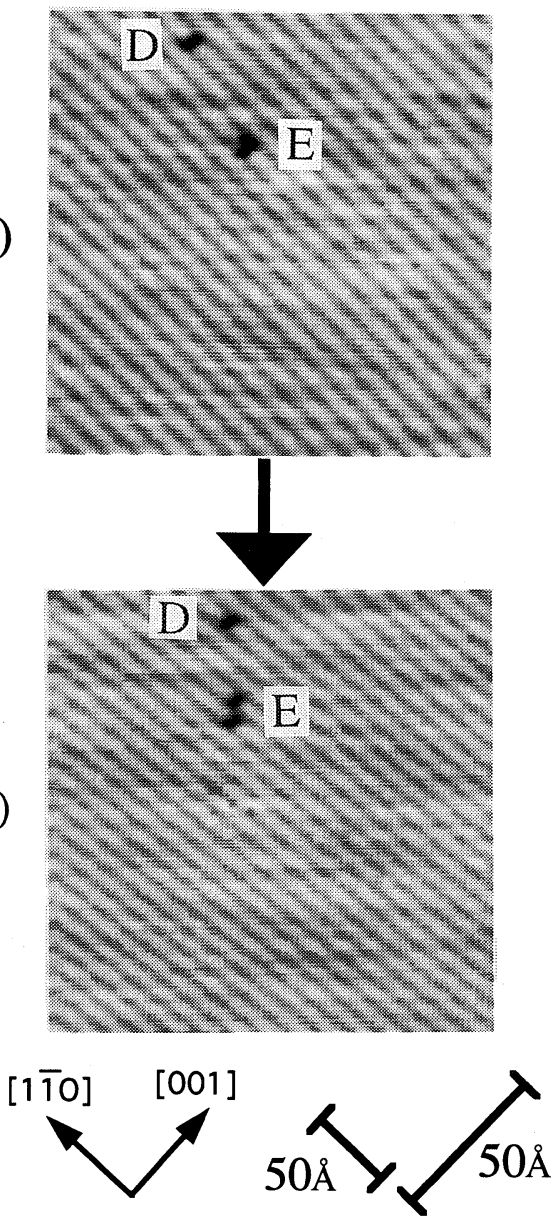

図 $5 \operatorname{InP}(110)$ 䢃開表面の非接触モードAFM 観察 結果.

(a) 画像上部の D と E に原子欠陥が観察され た。

(b) 80秒後に(a)と同じ領域を観察した結果， $\mathrm{D}$ と $\mathrm{E}$ の位置が離れ，また $\mathrm{E}$ の欠陥が $2 つ$ に分裂した。

に 2 格子列離れているが，80秒後に得られた図 $5(\mathrm{~b})$ で

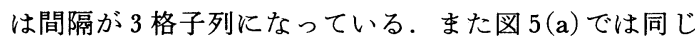
格子列上にあった Eの欠陥が，図 5(b)では違う格子列 に分裂している．この欠陥の移動の原因としては，熱拡 散や探針と試料表面との相互作用などが考えられる，通 常，探針先端の 1 個の原子之試料表面の 1 個の原子の間 に働く力により単原子の塑性変形を起こすには, 0.1 $\mathrm{nN}$ 数 $\mathrm{nN}$ 程度の斥力が必要であると推定されている. 非接触モードで動作する AFM の場合には, $10 \mathrm{pN}$ 程度 の非常に弱い引力を用いて括り，探針と試料表面との相
互作用は非常に弱い，したがって，この久陥の移動は， 熱払散によるものと考えられる。なお，AFMにより欠 陥の移動を観察したのは，本研究が初めてである.

これまで，欠陥の移動に関する研究は，STMを用い て盛んに行われてきた。しかし，STMの場合には，バ イアスされた探針を用いるため探針先端と試料表面との 間に非常に強い電場が生じたり，あるいは，トンネル電 流が局所的に流れるため試料表面が局所的に加熱された りする．室温では，このような強い電場による刺激やト ンネル電流によるエネルギー注入より，欠陥が移動して いる可能性が非常に高く，你の熱拡散を純粋に観察す ることは極めて困難であった ${ }^{23)}$. したがって，これらの 結果は, 欠陥の動的過程の研究に非接触モード UHV$\mathrm{AFM}$ が極めて有用なサイェンスッールになりらること を示唆している。

\section{4. ¿ め}

本研究は,「探針先端の 1 個の原子と試料表面の 1 個 の原子との間に㗢く単一の原子間力を測定できるの か?」といら AFM 動作の本質的な課題を明らかにする ことを目的にして行ったものである．具体的には，周波 数変調（FM）を利用した超高感度な UHV-AFMを開 発し, 非接触モード（引力領域）での単原子観察の可能 性を追求した，その結果, InP 化合物半導体の (110)䢃 開表面に対して, $4 \times 10^{-3} \mathrm{~N} / \mathrm{m}$ 程度の引力勾配領域で 原子像だけでなく，原子レベルの欠陷や吸着物の観察に も成功した．また，原子レベルの欠陥が移動する様子を AFM で初めて観察することにも成功した。探針と試料 表面との相互作用は非常に弱いので，この久陷の移動は 熱拡散によるものである可能性が高い。これらの結果 は, 非接触モードUHV-AFM が, 半導体清浄表面の実 空間における構造解析だけでなく, 欠陥の動的過程の研 究に拈いても極めて有用なサイェンスッールになりらる ことを示唆している.

\section{謝 辞}

本研究を進めるにあたり，有益なご議論をいただきま した光技術研究開発(侏)の逢坂福信博士（現富士通研究 所), 大河内俊介氏，ならびに日本電信電話(侏)境界領域 研究所の鈴木峰晴氏に感謝致します。また，原子間力顕 徽鏡ユニットの設計・製作において援助していただきま したオリンパス光学工業(侏)の三島周三氏，長岡秀樹氏に 感謝致します.

また，本研究は文部省科学研究費補助金の援助を受け ました。ここに記して感謝致します。 


\section{〔文献〕}

1) G. Binnig, C. F. Quate and Ch. Gerber: Phys. Rev. Lett. 56, 930 (1986).

2) F. F. Abraham and I. P. Batra: Sur. Sci. 209, L125 (1989).

3) L. Howald, E. Meyer, R. Lüthi, H. Haefke, R. Overney, H. Rudin and H. -J. Güntherodt: Appl. Phys. Lett. 63, 117 (1993).

4) F. J. Giessibl and G. Binnig: Ultramicroscopy 4244, 281 (1992).

5) M. Ohta, T. Konishi, Y. Sugawara, S. Morita, M. Suzuki and Y. Enomoto: Jpn. J. Appl. Phys. 32, 2980 (1993).

6) G. Binnig: Ultramicroscopy 42-44, 7 (1992).

7) F. Ohnesorge and G. Binnig: Science 260, 1451 (1993).

8) L. Howald, H. Haefke, R. Lüthi, E. Meyer, G. Gerth, H. Rudin and H. -J. Güntherodt: Phys. Rev. B49, 5651 (1994).

9) M. Kageshima, H. Yamada, Y. Morita, H. Tokumoto, K. Nakayama and A. Kawazu: Jpn. J. Appl. Phys. 32, L1321 (1993).

10) L. Howald, R. Lüthi, E. Meyer, P. Günhner and H. -J. Güntherodt: Z. Phys. B93, 267 (1994).

11) M. Ohta, Y. Sugawara, K. Hontani, S. Morita, F. Osaka, M. Suzuki, H. Nagaoka, S. Mishima and T.
Okada: Jpn. J. Appl. Phys. 33, L52 (1994).

12) Y. Sugawara, M. Ohta, K. Hontani, S. Morita, F. Osaka, S. Ohkouchi, M. Suzuki, H. Nagaoka, S. Mishima and T. Okada: Jpn. J. Appl. Phys. 33, 3739 (1994).

13) M. Ohta, Y. Sugawara, F. Osaka, S. Ohkouchi, M. Suzuki, S. Mishima, T. Okada and S. Morita: J. Vac. Sci. Technol. B13, 1265 (1995).

14) Y. Sugawara, M. Ohta, H. Ueyama and S. Morita: Jpn. J. Appl. Phys. 34, L462 (1995).

15) L. Howald, E. Meyer, R. Lüthi, H. Haefke, R. Overney, H. Rudin and H. -J. Güntherodt: Appl. Phys. Lett. 63, 117 (1993).

16) F. J. Giessibl: Jpn. J. Appl. Phys. 33, 3726 (1994).

17) F. J. Giessibl: Science 267, 68 (1994).

18) S. Kitamura and M. Iwatsuki: Jpn. J. Appl. Phys. 34, L145 (1995).

19) H. Ueyama, M. Ohta, Y. Sugawara and S. Morita: Jpn. J. Appl. Phys. 34, L1086 (1995) (印刷中).

20) M. Ohta, Y. Sugawara, S. Morita, H. Nagaoka, S. Mishima and T. Okada: J. Vac. Sci. Technol. B12, 1705 (1994).

21) D. Rugar, H. J. Mamin and P. Guethner: Appl. Phys. Lett. 55, 2588 (1989).

22) T. R. Albrecht, P. Grütter, D. Horne and D. Rugar: J. Appl. Phys. 69, 668 (1991).

23) Ph. Ebert, G. Cox, U. Poppe and Urban: Ultramicroscopy 42-44, 871 (1992). 